\title{
Pirbenicillin Sodium
}

National Cancer Institute

\section{Source}

National Cancer Institute. Pirbenicillin Sodium. NCI Thesaurus. Code C76226.

The sodium salt form of pirbenicillin, a broad-spectrum semisynthetic penicillin with antibacterial activity. Pirbenicillin binds to and inactivates the penicillin binding proteins (PBPs) located inside the bacterial cell wall. Inactivation of PBPs interferes with the crosslinkage of peptidog lycan chains necessary for bacterial cell wall strength and rigidity. This interrupts bacterial cell wall synthesis and results in the weakening of the bacterial cell wall, eventually causing cell lysis. 